\title{
Identifikasi Fishing Ground Ikan Teri (Stolephorus sp) Menggunakan Citra Modis di Perairan Karimunjawa, Jepara
}

\author{
Rizky Aditya $\mathbf{N}^{1}$, Anindya Wirasatriya ${ }^{1,2 *}$, Kunarso, Lilik Maslukah ${ }^{1,2}$, Petrus Subardjo ${ }^{1}$, \\ Agus Anugroho Dwi Suryosaputro ${ }^{1}$, Gentur Handoyo ${ }^{1}$ \\ ${ }^{I}$ Departemen Oseanografi, Fakultas Perikanan dan Ilmu Kelautan, Universitas Diponegoro \\ Jl. Prof. Soedarto, SH, Tembalang, Semarang, Jawa Tengah, 50275 \\ ${ }^{2}$ Pusat Kajian Mitigasi Bencana dan Rehabilitasi Pesisir, Universitas Diponegoro \\ Jl. Prof. Soedarto, SH, Tembalang, Semarang, Jawa Tengah, 50275 \\ Email : aninosi@yahoo.co.id
}

\begin{abstract}
Abstrak
Fishing ground atau zona penangkapan ikan adalah suatu kawasan perairan yang menjadi sasaran dalam usaha penangkapan ikan. Ikan teri merupakan hasil tangkapan ikan yang populer di Karimunjawa. Penelitian ini bertujuan memprediksi zona tangkapan ikan di Perairan Karimunjawa berdasarkan sebaran klorofil-a dan suhu permukaan laut dengan memanfaatkan data citra satelit Aqua Modis level-3. Sebaran klorofil-a yang tinggi terlihat pada bulan Mei sampai Juli. Nilai korelasi antara klorofil-a dengan tangkapan ikan di lapangan sebesar $\mathrm{r}=0,869$ yang berarti berhubungan sangat erat. Sedangkan nilai korelasi Suhu Permukaan Laut (SPL) dengan tangkapan ikan hanya sebesar $r=0,387$. Hal ini berarti hasil tangkapan ikan teri di Kepulauan Karimunjawa lebih dipengaruhi oleh sebaran klorofil-a dari pada SPL. Oleh karena itu dalam penentuan potensi fishing ground dengan menggunakan data MODI klimatologi bulanan, kami hanya menggunakan parameter klorofil-a. Perairan Karimunjawa memiliki kandungan klorofil-a rata rata sebesar $0,29 \mathrm{mg} / \mathrm{m}^{3}$. Berdasarkan analisa sebaran klorofil-a klimatologi bulanan, lokasi potensi fishing ground berada pada barat dan tenggara dari perairan Pulau Nyamuk, Barat Pulau Kemujan termasuk Pulau Cemara Besar dan Kecil, dan di perairan sekitar Pulau Parang yang dapat ditemukan disetiap bulannya.
\end{abstract}

Kata kunci: Fishing ground, Ikan Teri, Citra MODIS

\section{Abstract \\ Anchovy Ground Fishing Identification (Stolephorus sp) Using Fashionable Images in the Waters of Karimunjawa, Jepara}

Fishing ground or fishing zone is an area in the ocean which becomes a target for fishing activities. Common target for fishing activity in Karimunjawa is anchovy. The aim of this study is to predict fishing zone on the waters of Karimunjawa based on the chlorophyll distribution and sea surface temperature by utilizing level 3 Aqua MODIS data. The high chlorophyll-a distribution is observed from May to July. The correlation value between chlorophyll-a and fish catch based on insitu data is strong with $r=0.869$. Conversely, the correlation between insitu SPL correlation and fish catch is weak with $r$ $=0.38$. Therefore, we only used chlorophyll-a parameter to determine the potential fishing ground in Karimun Jawa. Karimunjawa waters have an average chlorophyll-a conscentration of $0.29 \mathrm{mg} / \mathrm{m}^{3}$, Based on monthly climatology of MODIS chlorophyll data, the location of potential fishing ground is west and southeast from the waters of the island of Nyamuk, the west of Kemujan Island including Pulau Cemara Besar and Kecil, and in the waters around Parang Island which can be found every month.

Keywords: Fishing Ground, Anchovy, Aqua MODIS

\section{PENDAHULUAN}

Zona tangkapan ikan (Fishing Ground) adalah suatu daerah atau lokasi sasaran untuk menangkap ikan di perairan laut. Salah satu ciri fishing ground yaitu terdapat banyak gerombolan ikan didalamnya (Mursyidin et al., 2015). Ikan teri merupakan salah satu target tangkapan nelayan di Kepulauan Karimunjawa. Pada umumnya 
nelayan tradisional di Karimunjawa di dalam menentukan zona tangkapan masih berdasarkan pengalaman dan kemampuan panca indra saja. Nelayan Karimunjawa mayoritas masih menggunakan cara-cara konvensional untuk menangkap ikan yaitu dengan mengandalkan pengalaman dengan pemanfaatan panca indra (Saifudin et al., 2014). Oleh karena itu hasil tangkapan nelayan tradisional Karimunjawa biasanya fluktuatif berdampak pada kesejahteraan nelayan itu sendiri.

Banyaknya ikan yang ada di lokasi zona tangkapan ikan dapat diketahui melalui parameter oseanografi di perairan tersebut. Parameter oseanografi perairan yang digunakan untuk mendekteksi adanya fishing ground adalah Suhu Permukaan Laut (SPL) dan Klorofil-a (Mursyidin et al., 2015). Kriteria suatu perairan dikategori sebagai zona fishing ground adalah memiliki nilai kandungan kosentrasi klorofil-a $>0.2 \mathrm{mg} / \mathrm{m}^{3}$ dan SPL yang ideal untuk penentuan potensi tangkapan ikan pelagis kecil berkisar antara $29^{\circ} \mathrm{C}-30^{\circ} \mathrm{C}$ (Kunarso, 2005).

Pada penelitian ini penulis menggunakan teknologi citra satelit Aqua MODIS untuk membantu menentukan daerah potensi fishing ground bagi nelayan tradisional setempat. Citra Aqua MODIS menghasilkan data data tentang parameter penggunaan citra satelit Aqua MODIS adalah datanya sudah berupa produk sehingga data tersebut dapat langsung diolah dan juga dapat mencangkup luasan daerah penelitian yang sangat luas dan dalam waktu yang singkat. Kami menguji oseanografi ang berhubungan dengan tangkapan ikan. Keunggulan dari parameter SST dan klorofil-a terhadap hasil tangkapan ikan teri secara insitu, dimana hasil analisis data insitu tersebut kami gunakan sebagai dasar penentuan zona potensi fishing ground dengan menggunakan data citra MODIS. Jadi, penelitian ini menggunakan kombinasi data lapangan (klorofil-a, SPL, tangkapan ikan) dengan data citra satelit klorofil-a Aqua MODIS untuk menentukan daerah fishing ground.

Tujuan dari penelitian ini adalah mengetahui hubungan faktor oseanografi (SPL dan Klorofil-a) dengan tangkapan ikan teri, menentukan daerah Fishing Ground Ikan Teri dengan menggunakan citra satelit aqua MODIS dan meneliti faktor yang mempengaruhi variabilitas parameter oseanografi di perairan Karimunjawa

\section{MATERI DAN METODE}

Materi yang digunakan dalam penelitian ini terdiri dari data klorofil-a, dan SPL, didapat secara insitu. Selain itu juga juga digunakan data klorofil- a dan SPL didapat dari citra satelit yang diunduh dari website www.oceancolour.nasa.gov dengan resolusi 4 Km dan waktu perekaman Januari 2011 sampai Desember 2016 . Produk MODIS klorofil-a diproduksi dengan menggabungkan dua algoritma, yaitu algoritma rasio band O'Reilly [Ocx] (O'Reilly et al., 1998) dan algoritma indeks warna $[\mathrm{CI}](\mathrm{Hu}, 2012)$. Algoritma CI dan Ocx digunakan untuk pengambilan klorofila masing-masing di bawah $0,15 \mathrm{mg} / \mathrm{m}^{3}$ dan di atas $2,0 \mathrm{mg} / \mathrm{m}^{3}$. Di antara nilai-nilai ini, keduanya algoritma dicampur dengan metode pembobotan. Sedangkan untuk MODIS SPL $11 \mu \mathrm{m}$ dihasilkan oleh algoritma Multichannel SPL dengan menggunakan suhu kecerahan pada $11 \mu \mathrm{m}$ dan 12 $\mu \mathrm{m}$ (Brown dan Minnett, 2009).

Data MODIS ini dikembangkan dan didistribusikan oleh National AS Aeronautika dan Administrasi Luar Angkasa (NASA) dan the Ocean Biology Processing Group. MODIS adalah platform operasional penginderaan warna laut dan juga banyak digunakan untuk investigasi fenomena oseanografi di laut. Data ini juga telah diuji dan divalidasi terhadap pengukuran in situ untuk memastikan yang terbaik akurasi. (Moore et al., 2009) dan (Zhang et al., 2006).

Data penunjang yang digunakan adalah data angin Karimunjawa dari website $w w w . e c m w f . i n t$ dengan resolusi $4 \mathrm{Km}$ dengan data diambil setiap bulan dari Januari 2011 sampai Desember 2016. Penentuan lokasi titik pengambilan sampel dilakukan dengan menggunakan metode purposive sampling yang menggunakan Global Positioning System (GPS) yang lokasinya berdasarkan titik daerah penangkapan nelayan setempat dan juga menurut hasil olah citra satelit. Kegiatan pengambilan data di lapangan dilakukan selama 2 hari yaitu pada tanggal 19 Mei dan 20 Mei 2017 dengan jumlah titik yang diambil sebanyak 11 titik. Peta lokasi penelitian ditampilkan pada Gambar 1 .

Pengumpulan data dalam penelitian ini yaitu, pengambilan data citra satelit dan pengambilan data langsung dari lapangan. Pengambilan data di lapangan bertujuan untuk mengidentifikasi zona tangkapan ikan teri di perairan Karimunjawa setelah itu data citra satelit Aqua MODIS digunakan untuk menentukan daerah fishing ground.

Pengukuran SPL, dan Klorofil-a secara insitu dalam penelitian ini dilakukan pada saat 


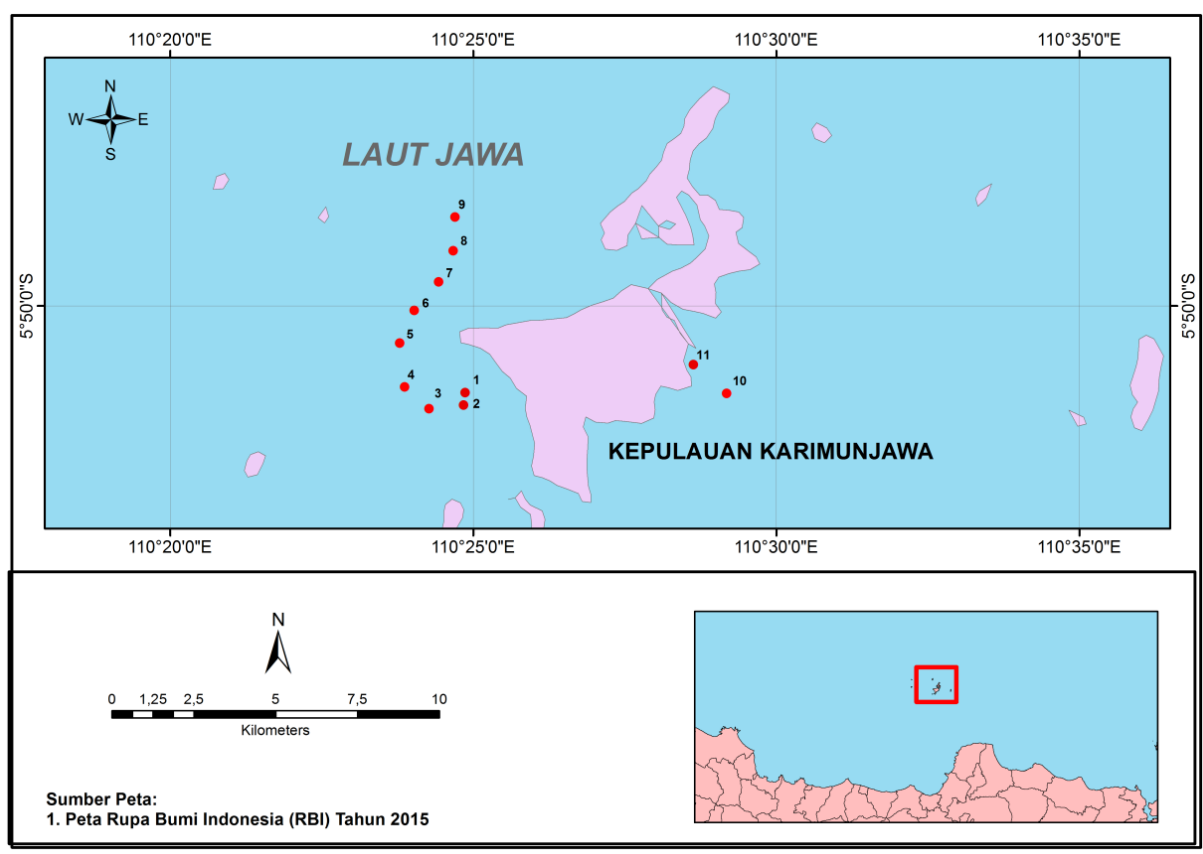

Gambar 1. Peta Lokasi Penelitian.

kapal nelayan berhenti pada titik yang sudah ditentukan. Setelah kapal berhenti lalu SPL diukur menggunakan alat thermometer air raksa $\left({ }^{\circ} \mathrm{C}\right)$, Klorofil-a diambil dalam botol sampel 1 liter $\left(\mathrm{mg} / \mathrm{m}^{3}\right)$, dan tangkapan ikan diambil selama dua jam per stasiun.

\section{Pengolahan Data Citra}

Pengolahan data SPL dan Klorofil- a dilakukan dengan menggunakan berbagai macam software. Dilakukan pemotongan citra yang sesuai untuk membatasi wilayah yang diteliti. Data tersebut kemudian di proses untuk menghasilkan output berupa format GeoTIFF, yang selanjutnya hasil tersebut digambarkan secara visual berupa peta suhu permukaan laut dan klorofil-a.

Data angin yang digunakan adalah data angin ECMWF (http://www.ecmwf.int). Data yang digunakan dalam penelitian ini merupakan data setiap bulan dari tahun 2011 sampai tahun 2016. Parameter yang digunakan untuk mengetahui kecepatan dan arah angin yaitu $\mathrm{v}$ dan u. Titik koordinat dimasukkan untuk membatasi wilayah kajian. Grid yang dipilih adalah 0,125 karena wilayah kajian Kepulauan Karimunjawa termasuk wilayah yang kecil. Data yang telah diunduh kemudian diekstrak dan dihitung rataratanya. Menggunakan rumus resultan untuk menghitung nilai komponen arah $(\theta)$ dan kecepatan (v). Setelah di dapat arah dan kecepatannya kemudian di gambarkan secara visual dalam bentuk peta.

\section{Metode Klimatologi}

Metode klimatologi yang harus dilakukan adalah menggabungkan semua data klorofil-a bulanan ke dalam klimatologi bulanan untuk melihat distribusi spasial lautan selama periode dari 2011 hingga 2016. Menurut Wirasatriya et al., (2017) rumus dalam melakukan penggabungan data klimatologi menggunakan persamaan berikut:

$$
\bar{X}(x, y)=\frac{1}{n} \sum_{i=1}^{n} x i(x, y, t)
$$

Dimana $X(x, y)$ adalah nilai rata-rata bulanan atau klimatologi bulanan nilai pada posisi $(\mathrm{x}, \mathrm{y})$. $\mathrm{xi}(\mathrm{x}, \mathrm{y}, \mathrm{t})$ adalah nilai dari data pada $(\mathrm{x}, \mathrm{y})$ posisi dan waktu t.

Selanjutnya, $\mathrm{n}$ adalah jumlah data dalam 1 bulan dan jumlah data bulanan dalam 1 periode klimatologi (yaitu, dari tahun 2011 hingga 2016) untuk perhitungan bulanan dan perhitungan klimatologi bulanan, masing-masing. Jika xi adalah lubang pixel, piksel itu dikecualikan dalam perhitungan.

\section{Analisis Klorofil-a}

Kandungan klorofil-a di perairan menggunakan panjang gelombang yang berbeda yaitu $647 \mathrm{~nm}, 630 \mathrm{~nm}, 665 \mathrm{~nm}$ dan $750 \mathrm{~nm}$ (APHA, 1992, Riyono \& Hadi., 2006, Maslukah et al., 2018). Selanjutnya Konsentrasi klorofil-a dihitung menggunakan formula berikut :

$\mathrm{Ca}=11.85(\lambda 664)-1.54(\lambda 645)-0.08(\lambda 630)$

Klo-a $\left(\mathrm{mg} / \mathrm{m}^{3}\right)=\mathrm{Ca} \times \mathrm{v} / \mathrm{V}$ 
Dimana : $\lambda 664, \lambda 645$, dan $\lambda 630=$ pembacaan nilai absorbansi pada panjang gelombang tersebut, $\mathrm{v}=$ volume ekstrak (liter), V = volume sampel $\left(\mathrm{m}^{3}\right)$

\section{Analisis Data}

Menurut (Sugiyono, 2009) analisis korelasi menyatakan derajat keeratan hubungan antar variabel. Pada analisis ini digunakan analisis korelasi bivariate untuk mencari derajat keeratan hubungan antara variabel SPL dengan klorofil-a, SPL dengan angin, Klorofil-a dengan angin, dan semua dengan hasil tangkapan. Semakin tinggi nilai korelasinya makan semakin tinggi pula tingkat keeratan hubungan antar variabel.

Pada analisis korelasi bivariate digunakan pengujian Pearson untuk mengetahui hubungan data yang terdistribusi normal dengan menggunakan rumus korelasi Pearson menurut Sugiyono (2009).

Nilai dari koefisien korelasi (r) memiliki kisaran antara $0-(+/-) 1$ (Tabel 1). Tanda positif menunjukan arah hubungan yang searah, sedangkan negatif menunjukkan hubungan yang berlawanan.

\section{HASIL DAN PEMBAHASAN}

\section{Hasil Data Lapangan (Klorofil-a, SPL, Tangkapan Ikan)}

Hasil pengolahan data klorofil-a menunjukkan kandungan klorofil-a yang paling rendah terdapat pada stasiun 6 dengan 0,117 $\mathrm{mg} / \mathrm{m}^{3}$ dan kandungan klorofil-a terbesar terdapat pada stasiun 9 dengan $0,575 \mathrm{mg} / \mathrm{m}^{3}$ (Tabel 2).

Hasil data lapangan klorofil-a dengan tangkapan ikan teri secara spasial ditampilkan pada Gambar 2. Perbedaan warna menunjukan kandungan klorofil-a dan ukuran lingkaran menunjukkan hasil tangkapan ikan teri. Stasiun 6 memiliki kandungan klorofil-a yang paling rendah dan diikuti hasil tangkapan ikan teri yang juga rendah. Stasiun 10 memiliki kandungan klorofil-a yang sedang $(0,3 \mathrm{mg} / \mathrm{m} 3)$ dan diikuti oleh hasil tangkapan ikan teri yang juga sedang

Tabel 1. Korelasi Pearson (Sugiyono, 2009)

\begin{tabular}{cc}
\hline Interval Koefisien Korelasi & Tingkat Hubungan \\
\hline $0,00-0,19$ & Sangat Rendah \\
$0,20-0,39$ & Rendah \\
$0,40-0,59$ & Agak rendah \\
$0,60-0,79$ & Kuat \\
$0,80-1,00$ & Sangat Kuat \\
\hline
\end{tabular}

(4kg). Stasiun 11 memiliki kandungan klorofil-a yang paling tinggi $\left(0,5 \mathrm{mg} / \mathrm{m}^{3}\right)$ dan diikuti hasil tangkapan ikan teri yang paling banyak $(8 \mathrm{~kg})$.

Hasil data lapangan klorofil-a dengan tangkapan ikan teri secara statistik ditampilkan pada Gambar 4. Grafik scatter antara klorofil-a dengan hasil tangkapan ikan menunjukkan nilai korelasi yang tinggi yaitu dengan nilai $\mathrm{R}=0,869$ dengan kata lain nilai tersebut sangat kuat menurut perhitungan pearson (Tabel 1). Menurut penelitian dari Prastianto (2016) menyebutkan bahwa proses penyebaran klorofil-a di perairan akan menyebabkan ikan kecil pelagis dan organisme lain berkumpul ke daerah yang memiliki konsentrasi klorofil-a yang tinggi.

Hasil data SPL dengan tangkapan ikan teri secara spasial ditampilkan pada Gambar 3. Stasiun 7 dan 11 memiliki SPL yang berbeda tetapi memiliki hasil tangkapan ikan teri yang sama (1-3kg) dan stasiun 4 dan 9 memiliki SPL yang sama tinggi tetapi berbeda hasil tangkapan ikan terinya. Hasil berupa statistik dari SPL dengan tangkapan ikan teri berupa scatter ditampilkan pada Gambar 5. SPL bisa dikatakan tidak memiliki pengaruh banyak terhadap tangkapan ikan teri di lapangan. SPL dan tangkapan ikan memiliki nilai $\mathrm{R}=0,387$ bisa diartikan nilai tersebut rendah menurut perhitungan pearson (Tabel 1). Selanjutnya nilai SPL tidak akan dibahas pada penelitian ini karena tidak banyak berpengaruh pada hasil tangkapan ikan menurut hasil penelitian.

\section{Peta Fishing Ground Perairan Karimunjawa}

Zona fishing ground yang baik menurut (Kunarso,2005) adalah daerah perairan yang memiliki kandungan klorofil- a $>0.2 \mathrm{mg} / \mathrm{m}^{3}$ dan SPL untuk ikan pelagis kecil yaitu $29^{\circ} \mathrm{C}-30^{\circ} \mathrm{C}$. Perairan Karimunjawa memiliki nilai kandungan klorofil-a yang tinggi dan hampir merata, sehingga jika menggunakan teori dari Kunarso (2005) seluruh perairan Karimunjawa dapat dikategorikan sebagai daerah tangkapan ikan yang potensial.

Berdasarkan pengambilan data lapangan yang dilakukan pada bulan Mei 2017 diketahui bahwa pada stasiun 11 yang terletak pada koordinat 110,441 dan $-5,808$ memiliki kandungan klorofil-a dan hasil tangkapan ikan teri tertinggi. Menurut data citra satelit Aqua MODIS klimatologi pada bulan Mei di stasiun 11 memiliki kandungan klorofil sebesar $0,77 \mathrm{mg} / \mathrm{m}^{3}$ dan terendah sebesar $0,2 \mathrm{mg} / \mathrm{m}^{3}$ dengan kecepatan angin rata rata sebesar $3,7 \mathrm{~m} / \mathrm{s}$.

Peta potensi tangkapan ikan ditampilkan pada Gambar 6. Hasil penelitian menunjukkan 
bahwa daerah potensi tangkapan ikan dibagi menjadi tiga golongan yaitu, rendah, sedang, dan tinggi yang dibagi menurut standar deviasi dengan nilai yang didapat sebesar 0,3 . Daerah tangkapan rendah memiliki kandungan klorofil-a $0,1 \mathrm{mg} / \mathrm{m}^{3}$ $\leq$ klorofil-a $\leq 0,3 \mathrm{mg} / \mathrm{m}^{3}$. Daerah tangkapan yang sedang memiliki kandungan klorofil-a $0,3 \mathrm{mg} / \mathrm{m}^{3}$ $\leq$ klorofil-a $\leq 0,6 \mathrm{mg} / \mathrm{m}^{3}$. Daerah tangkapan yang tinggi memiliki kandungan klorofil-a sebanyak $0,6 \quad \mathrm{mg} / \mathrm{m}^{3} \leq$ klorofil $-\mathrm{a} \leq 1 \quad \mathrm{mg} / \mathrm{m}^{3}$.Konsentrasi klorofil-a tertinggi terjadi pada bulan Mei-Agustus dengan rerata sebesar $3.6 \mathrm{mg} / \mathrm{m}^{3}$ (Gambar 6). Tingginya konsentrasi klorofil-a tersebut diduga dipengaruhi oleh beberapa faktor yaitu kecerahan perairan, dangkalnya perairan disekitar pulau dan peningkatan kecepatan angin. Hembusan angin yang mendorong terjadinya percampuran mekanik dan peningkatan flux nutrien dengan menigkatkan proses mixing secara vertikal dan pendalaman mixed layer, akhirnya kondisi ini ideal untuk fitoplankton tumbuh (Wirasatriya et al., 2017).

Tabel 2. Perhitungan Kandungan Klorofil-a di Laboratorium

\begin{tabular}{ccc}
\hline Stasiun & $\mathrm{C}$ & Klorofil-a $\left(\mathrm{mg} / \mathrm{m}^{3}\right)$ \\
\hline 1 & 0,02907 & 0,2907 \\
2 & 0,02362 & 0,2362 \\
3 & 0,022 & 0,22 \\
4 & 0,022 & 0,22 \\
5 & 0,02362 & 0,2362 \\
6 & 0,01177 & 0,1177 \\
7 & 0,02038 & 0,2038 \\
8 & 0,03385 & 0,3385 \\
9 & 0,05755 & 0,5755 \\
10 & 0,03547 & 0,3547 \\
11 & 0,02208 & 0,2208 \\
\hline
\end{tabular}

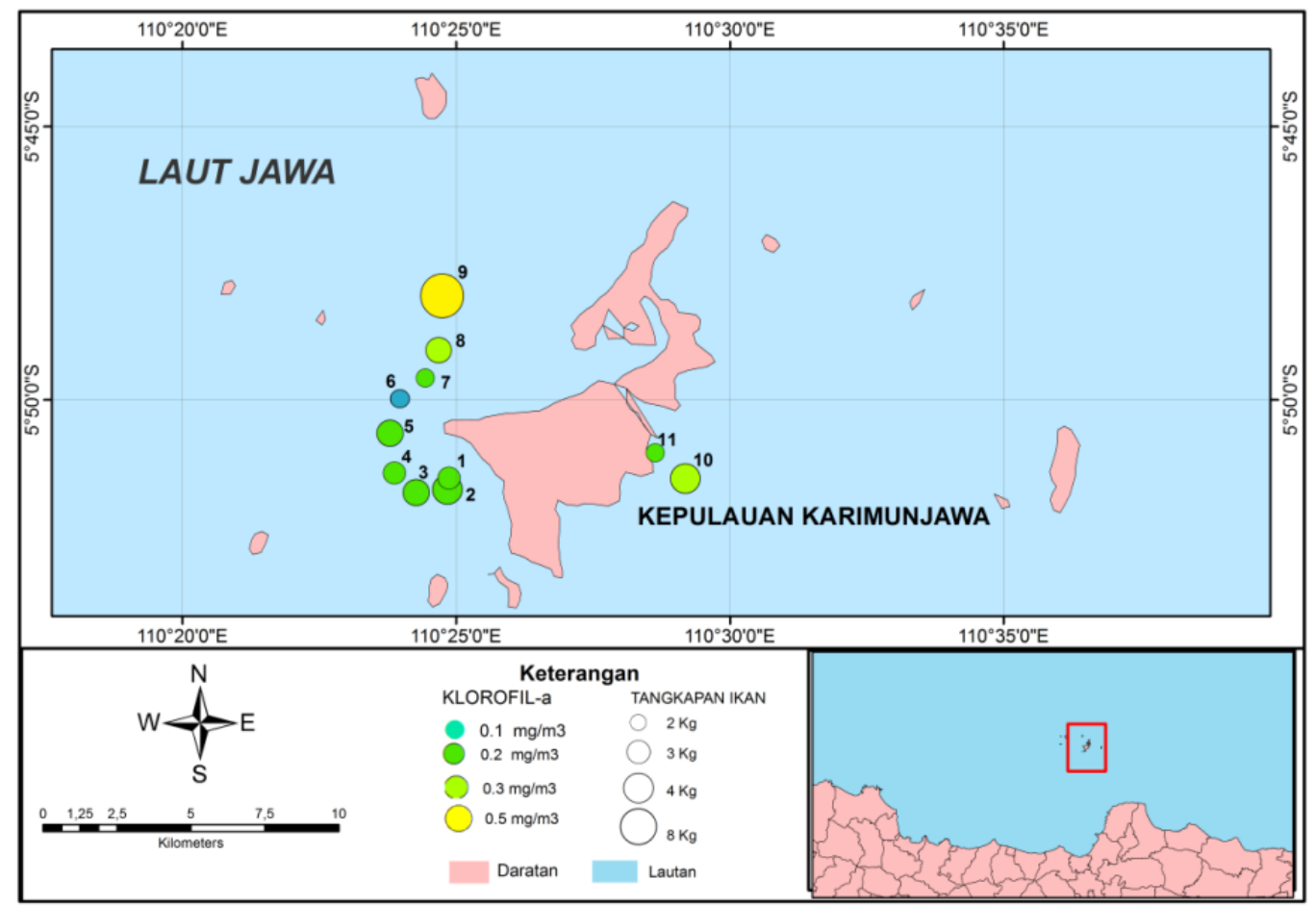

Gambar 2. Peta Hasil Tangkapan Ikan Teri di Lapangan Dihubungkan Dengan Konsentrasi Klorofil-a Pada Titik Yang Sama 


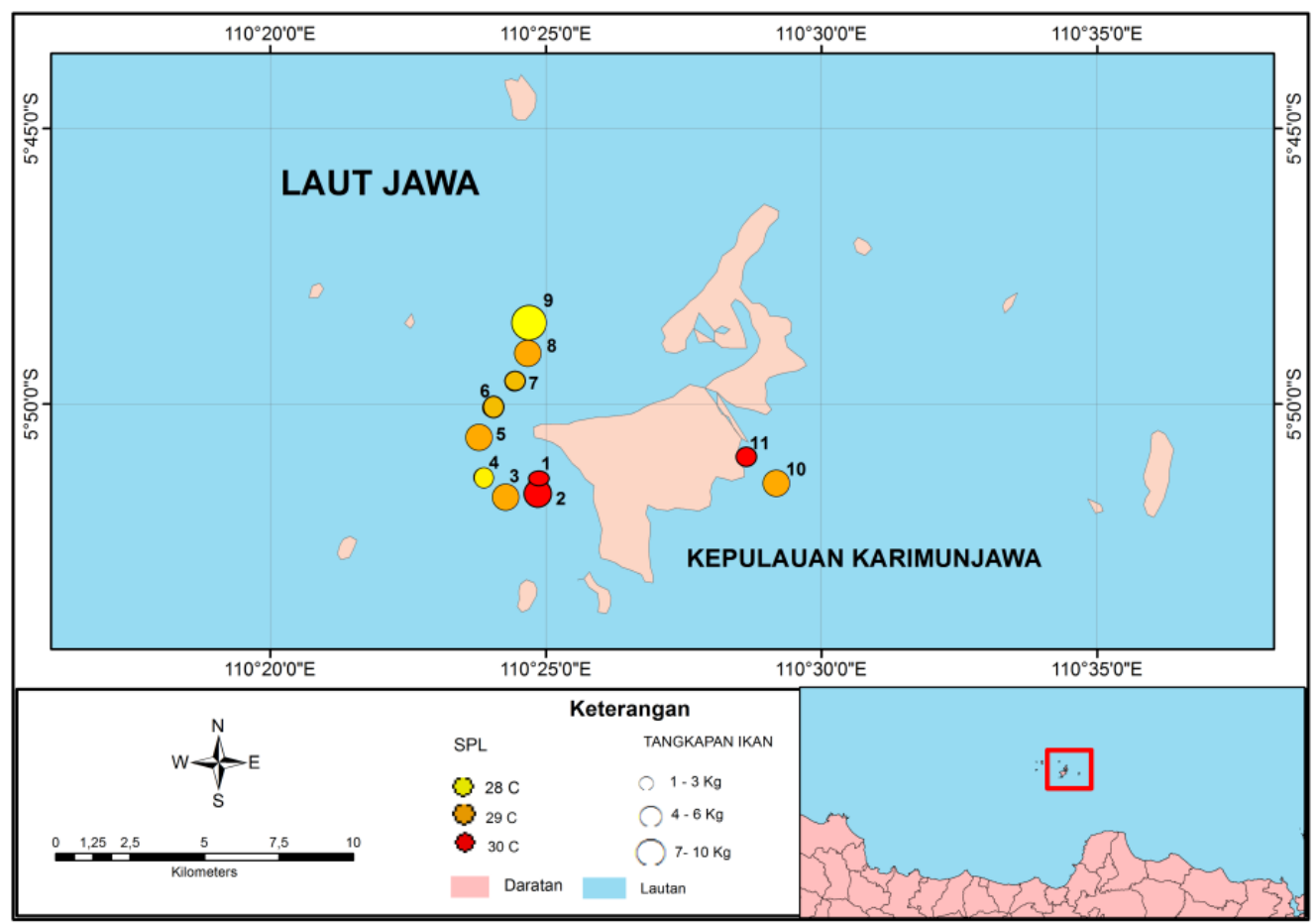

Gambar 3. Peta Hasil Tangkapan Ikan Teri di Lapangan Dihubungkan Dengan Suhu Permukaan Laut

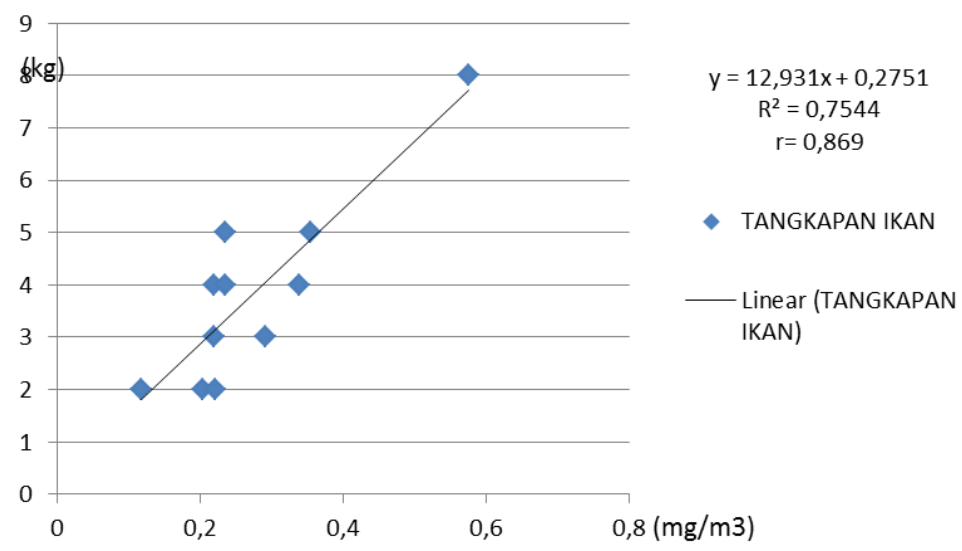

Gambar 4. Grafik scatter Klorofil-a vs Tangkapan Ikan

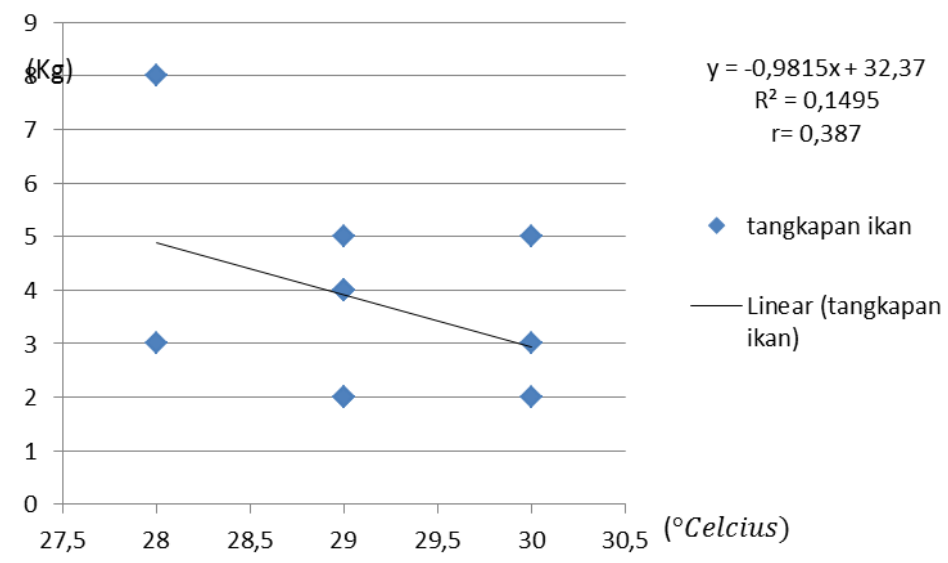

Gambar 5. Grafik scatter SPL vs Tangkapan Ikan 
Klorofil-a yang paling rendah terjadi pada bulan November dengan rerata sebesar 0,2 $\mathrm{mg} / \mathrm{m}^{3}$ (Gambar 6). Rendahnya konsentrasi klorofil-a tersebut diakibatkan oleh lemahnya kecepatan angin, dengan nilai kecepatan rata-rata angin pada bulan tersebut sebesar 1,47 $\mathrm{m} / \mathrm{s}$. Lemahnya kecepatan angin menjadikan proses mixing juga melemah sehingga

\section{JANUARI}

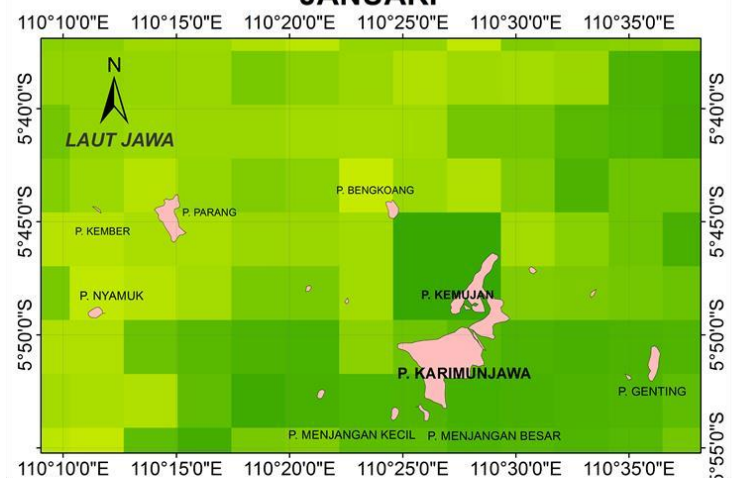

MARET
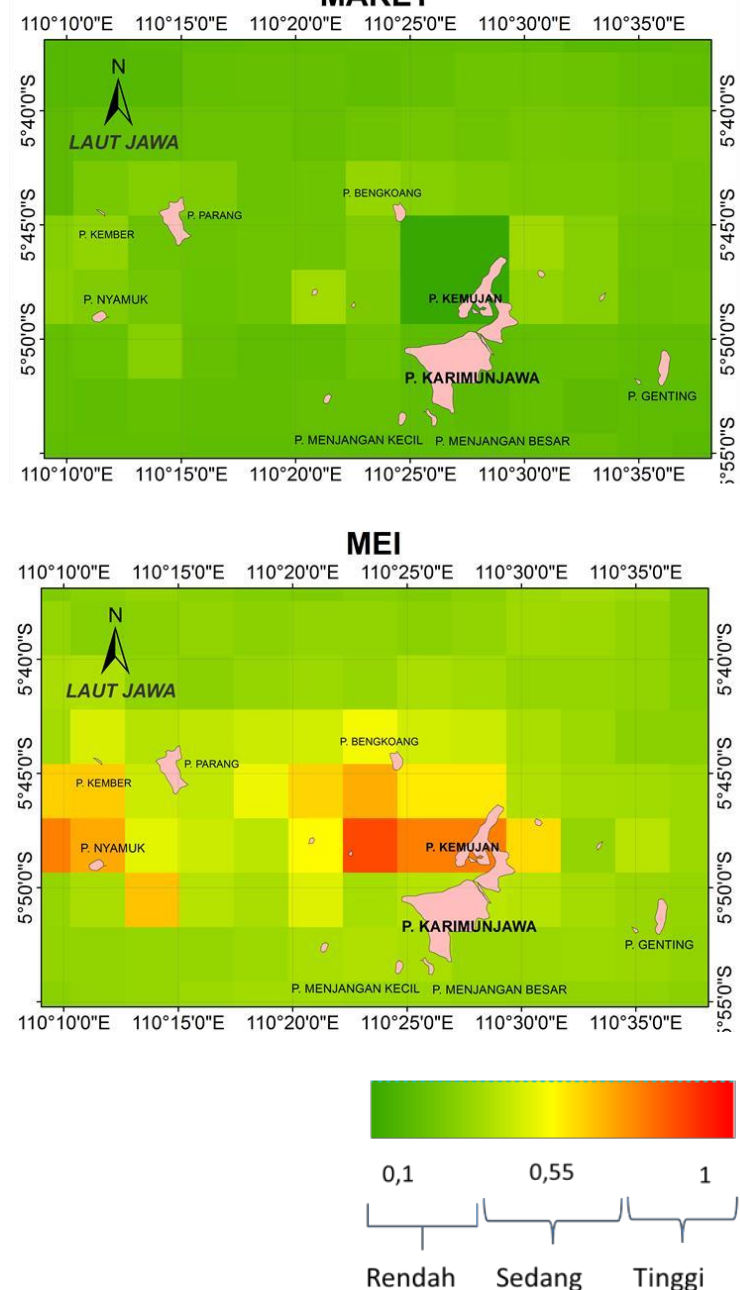

proses penyuburan perairan menjadi rendah. Hasil prediksi daerah tangkapan ikan yang termasuk potensial (kategori sedangtinggi) ada di beberapa tempat, yaitu barat dan tenggara dari perairan Pulau Nyamuk, Barat Pulau Kemujan termasuk Pulau Cemara Besar dan Kecil, dan di perairan sekitar Pulau Parang. Penentuan lokasi fishing ground

\section{FEBRUARI}

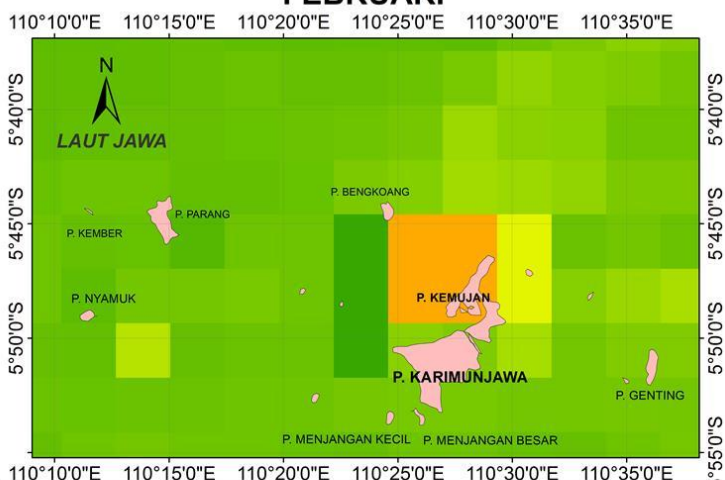

APRIL

$110^{\circ} 10^{\prime} 0^{\prime \prime E} \quad 110^{\circ} 15^{\prime} 0^{\prime \prime E} \quad 110^{\circ} 20^{\prime} 0^{\prime \prime E} \quad 110^{\circ} 25^{\prime} 0^{\prime \prime E} \quad 110^{\circ} 30^{\prime} 00^{\prime \prime E} \quad 110^{\circ} 35^{\prime} 0^{\prime \prime E}$

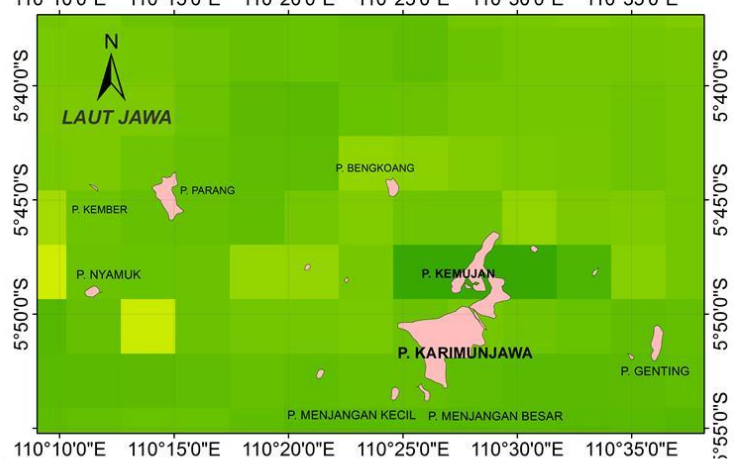

JUNI

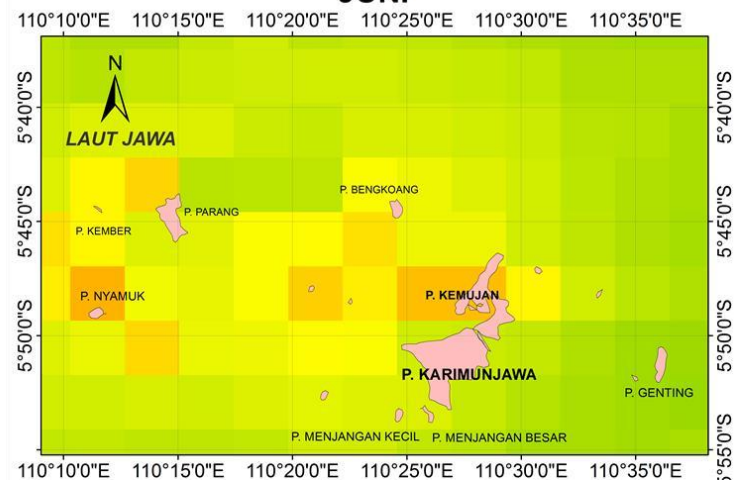

Kandungan Klorofil-a $\left(\mathrm{mg} / \mathrm{m}^{3}\right)$

Frekuensi Potens

Fishing Ground

Gambar 6 a. Peta Klimatologi Bulanan Klorofil-a dan Potensi Fishing Ground Ikan Teri Di Perairan Karimunjawa Pada Bulan Januari-Juni. 

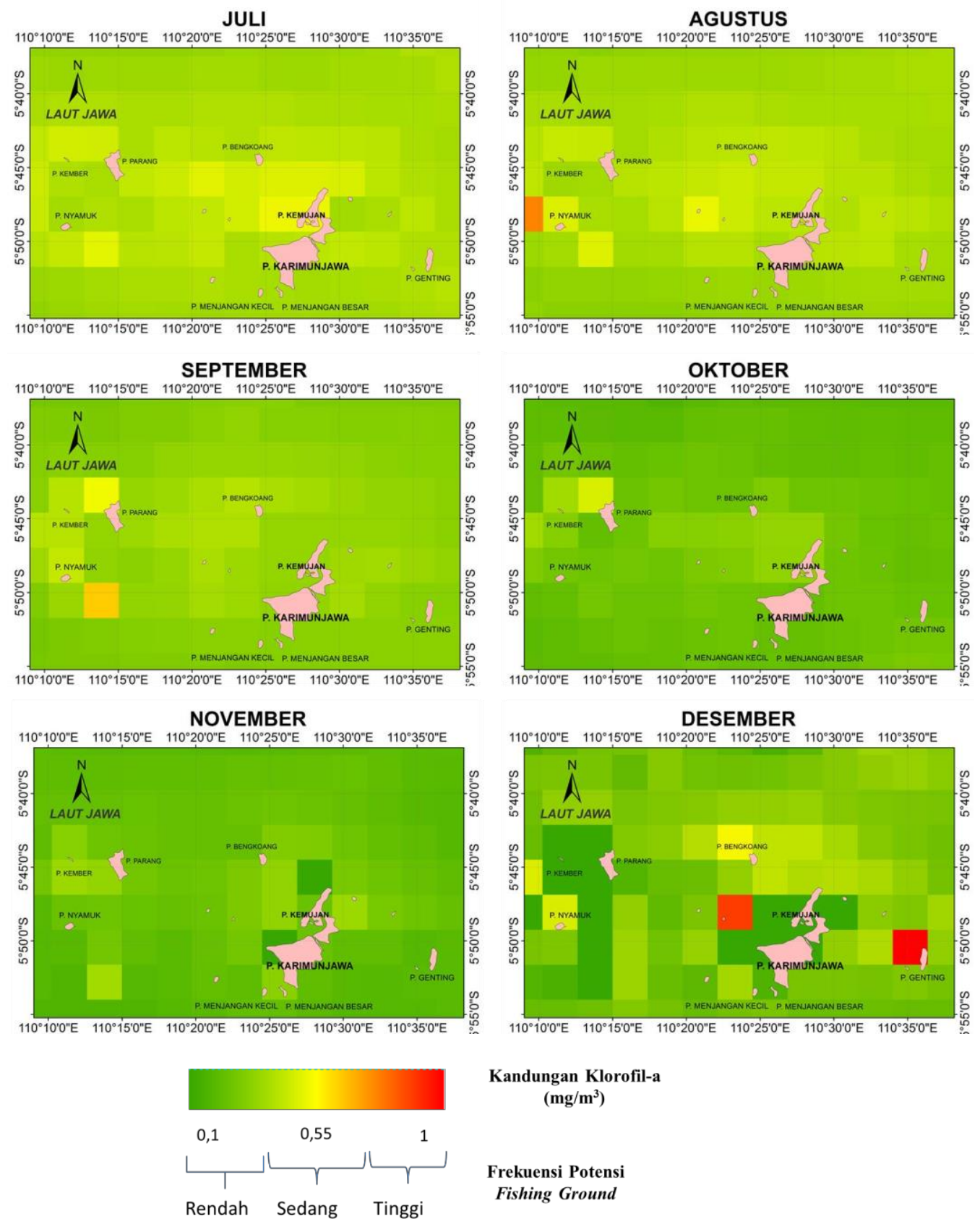

Kandungan Klorofil-a $\left(\mathrm{mg} / \mathrm{m}^{3}\right)$

Frekuensi Potensi Fishing Ground

Gambar 6 b. Peta Klimatologi Bulanan Klorofil-a dan Potensi Fishing Ground Ikan Teri Di Perairan Karimunjawa Pada Bulan Juli-Desember.

berdasarkan kandungan klorofil-a di daerah tersebut lebih tinggi dari daerah lain. Konsentrasi klorofil-a yang baik digunakan untuk menentukan fishing gorund adalah > 0,2 $\mathrm{mg} / \mathrm{m}^{3}$ (Kunarso, 2005).

\section{Distribusi Temporal Klorofil-a, Angin Secara Bulanan di Perairan Karimunjawa}

Grafik sebaran klorofil-a dan angin secara temporal ditampilkan pada Gambar 7 dan Gambar 8. Data klorofil-a menggunakan data citra Aqua MODIS dan data angin menggunakan
ECMWF bulanan selama enam tahun. Menurut penelitian dari Wirasatriya et al., (2017) menyebutkan bahwa klorofil-a di area perairan terbuka memiliki korelasi positif terhadap kecepatan angin (Gambar 7 dan Gambar 8).

Klorofil-a terlihat berubah-ubah setiap bulannya dan juga pola arah angin juga berubah menurut musimnya. Rerata klorofila tertinggi terlihat pada Bulan Juni $\left(0,41 \mathrm{mg} / \mathrm{m}^{3}\right)$ dengan arah angin menuju ke Barat Laut sebesar $4,01 \mathrm{~m} / \mathrm{s}$, dan rerata klorofil-a terendah pada Bulan November $\left(0,17 \mathrm{mg} / \mathrm{m}^{3}\right)$ dengan pola arah 


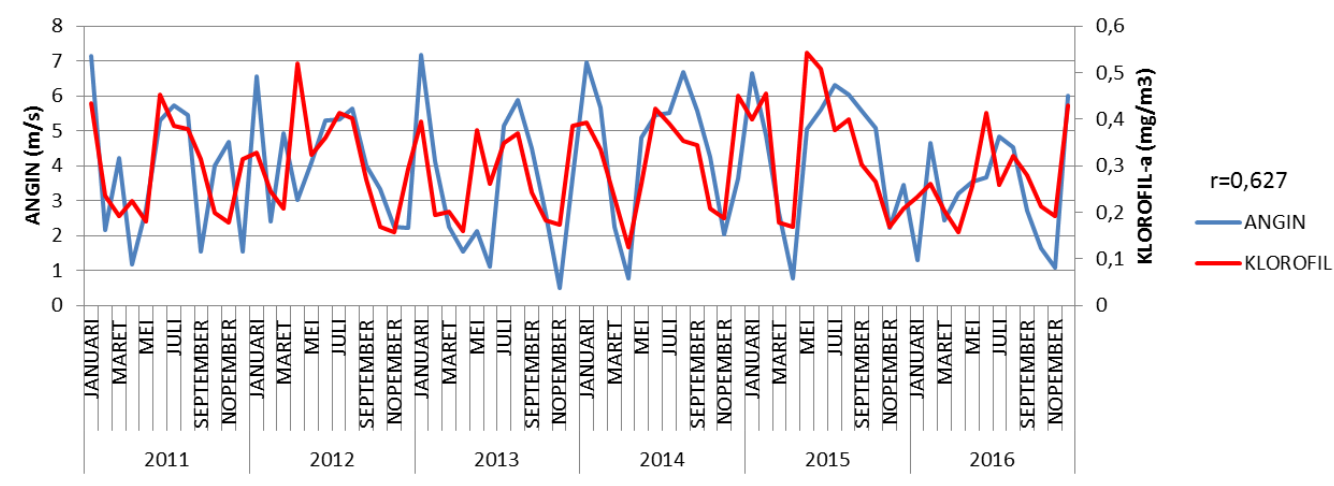

Gambar 7. Grafik Angin dan Klorofil-a Bulanan Selama Enam Tahun

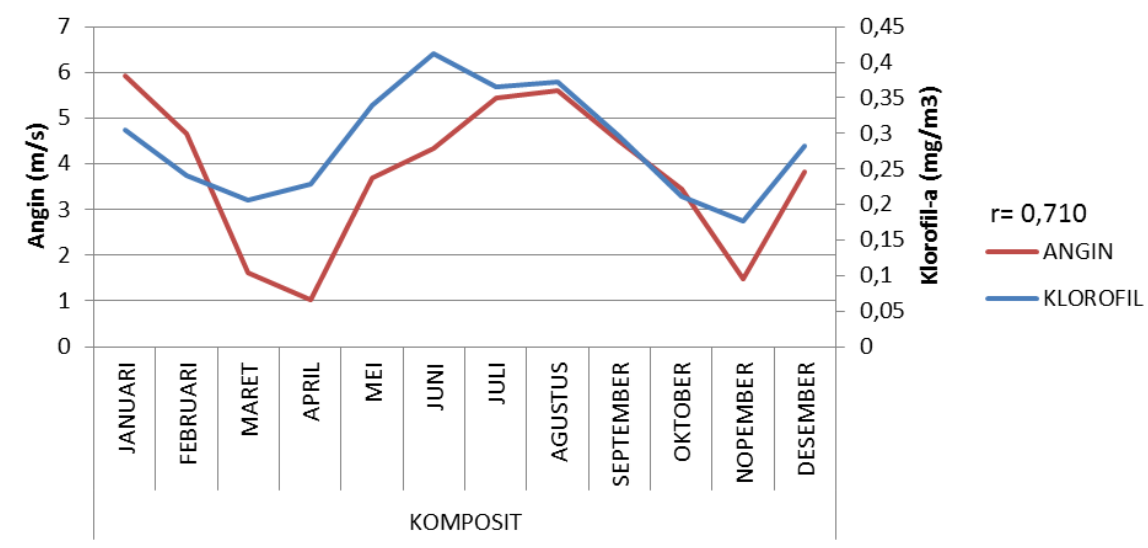

Gambar 8. Grafik Angin dengan Klorofil-a Klimatologi Bulanan Selama Enam Tahun.

angin menuju ke Barat Laut sebesar 1,54 m/s.

Distribusi angin bulanan di perairan Karimunjawa memiliki nilai tertinggi pada Bulan Januari $(5,9 \mathrm{~m} / \mathrm{s})$ dan Agustus $(5,6 \mathrm{~m} / \mathrm{s})$, sedangkan nilai terendah pada Bulan April (1,03 $\mathrm{m} / \mathrm{s})$ dan November $(1,5 \mathrm{~m} / \mathrm{s})$. Bila diamati sebaran klorofil-a di perairan Karimunjawa itu merata dan konstan dengan klorofil-a rata rata bernilai $0,28 \mathrm{mg} / \mathrm{m}^{3}$. Tinggi rendahnya kandungan klorofil-a di perairan dapat disebabkan oleh adanya angin, semakin tinggi kecepatan angin maka akan mengakibatkan meningkatnya proses mixing diperairan, mixing ini dapat meningkatkan juga produksi primer diperairan sehingga organisme pemakan plankton akan berkumpul di daerah tersebut. Begitu juga dengan sebaliknya semakin lemah kecepatan angin maka akan melemah juga proses mixing di perairan, sehingga mengakibatkan lemahnya produktivitas primer di perairan.

\section{KESIMPULAN}

Berdasarkan hubungan korelasi antara klorofil-a dengan tangkapan ikan teri menunjukkan sangat erat dengan nilai $\mathrm{r}$ sebesar 0,869. Sedangkan hubungan korelasi antara SPL dengan tangkapan ikan teri menunjukkan nilai rendah dengan $\mathrm{r}$ sebesar 0,387, yang mengindikasikan SPL tidak berpengaruh besar terhadap hasil tangkapan ikan teri. Berdasarkan analisis dari MODIS klorofil-a secara spasial Fishing Ground ikan teri yang potensial berada pada bagian barat dan tenggara perairan Pulau Nyamuk, Barat Pulau Kemujan termasuk perairan Pulau Cemara Besar dan Kecil, dan di perairan sekitar Pulau Parang. Sedangkan secara temporal, kandungan rerata klorofil-a tertinggi terdapat pada bulan Juni $\left(0,4 \mathrm{mg} / \mathrm{m}^{3}\right)$ dan terendah terdapat pada bulan November $\left(0,17 \mathrm{mg} / \mathrm{m}^{3}\right)$. Distribusi klorofil-a di perairan Karimunjawa dipengaruhi oleh angin, dengan korelasi sebesar $\mathrm{r}=0,71$

\section{DAFTAR PUSTAKA}

APHA. 1992. Standart method for the examnination of water dan wastewater. $18^{\text {th }}$ edition. Washington, 252p 
Brown, O.B. \& Minnett, P.J., 2009. MODIS infrared sea surface temperature algorithm theoretical basis document, Version 2.0.

Hu, C., Lee, Z. \& Franz, B., 2012. Chlorophyll a algorithms for oligotrophic oceans: A novel approach based on three-band reflectance difference, J. Geophys. Res., 117(C01011): 1-25. DOI : 10.1029/2011jc00 7395.

Kunarso. 2005. Kajian Penentuan Lokasi- Lokasi Upwelling Di Perairan Indonesia dan Sekitarnya Serta Kaitannya Dengan Fishing Ground tuna. [Thesis]. PS.Oseanografi, Saints Atmosfir dan Seismologi, ITB, Bandung, Hlm 250.

Maslukah, L., Wulandari, S. Y., Prasetyawan, I.B. \& Muslim. 2018. The Distributions Of N, P Nutrients And Its Relations with Chlorophyll-a : Case Study In Serang And Wiso Estuary, Jepara, Indonesia. Asian J. Microbiol. Biotechnol. Environ. Sci. 20(3): 123-129.

Moore, T.S., Campbell, J.W. \& Dowell, M.D., 2009. A. class-based approach to characterizing and mapping the uncertainty of the MODIS ocean chlorophyll product. Remote. Sens.Environ.113:2424-2430.

Mursyidin, Munadi, K., \& Muchlisin, Z.A. 2015. Prediksi Zona Tangkapan Ikan Menggunakan Citra Klorofil-a dan Citra Suhu Permukaan Laut Satelit Aqua MODIS di Perairan Pulo Aceh. J. Rekayasa Elektrika. 11(5):176-182

O'Reilly, J.E., Maritorena, S., Mitchell, B.G.,
Siegel, D.A., Carder, K.L., Garver, S.A. \& Kahru, M., McClain, C. 1998. Ocean color chlorophyll algorithms for SeaWiFS, Geophys. Res. Letters. 103:24937-24953

Riyono \& Hadi, S., 2006. Beberapa Metode Pengukuran Klorofil Fitoplankton di Laut. Jurnal Oseana. XXXI(3):33-34.

Saifudin, Fitri, A.D.P., \& Sardiyatmo. 2014. Aplikasi Sistem Informasi Geografis (GIS) Dalam Penentuan Daerah Penangkapan Ikan Teri (stolephorus sp) di Perairan Pemalang Jawa Tengah. J. Fish. Res. Utilization Manag. Technol. 3(4):66-75.

Sugiyono, 2009. Metode Penelitian Kuantitatif, dan R and D. Alfabeta, Bandung, hlm 380.

Wirasatriya, A., Prasetyawan, I.B, Triyono, C.D., Muslim \& Maslukah, L., 2017. Effect Of ENSO On The Variability Of SST And Chlorophyll-A In Java Sea. 3rd International Conference On Tropical And Coastal Region Eco-Development 2017, IOP Conferen. Ser. : Earth Environ. Sci. 116:012063

Wirasatriya, A., Setiawan, R.Y., \& Subardjo, P., 2017. Effect Of Enso On The Variability of Chlorophyll-A And SPL In The Maluku Sea. IEEE J. Selec. Topics App. Earth Observ. Remote Sens. 10:5513-5518

Zhang, C.,Hu, C., Shang, S., Karger, F.E.M., Li, Y., Dai, M., Huang, B., Ning, X. \& Hong, H. 2006. Bridging between SeaWiFS and MODIS for continuity of chlorophylla concentration assessments off Southeastern China, Remote Sens. Environ. 102:250-263. 